\title{
THE INFLUENCE OF BANCASSURANCE PRODUCTS AND RESPONSIVENESS TO CONSUMER BEHAVIOR AND CORPORATE IMAGE AS MEDIATION VARIABLES: A STUDY AT BANK METRO MADANI, METRO CITY
}

\author{
Suharto S.* \\ Faculty of Economics, Muhammadiyah University of Metro, Indonesia \\ Finny L. \\ Graduate Program, Muhammadiyah University of Metro, Indonesia \\ *E-mail: hartoumm@gmail.com
}

\begin{abstract}
Behavior of consumers is an important factor in the purchase decision. The purpose of research is to know the influence of bancassurance products, responsiveness and company image to the consumer behavior. This research, using primary data collected by the method of explanatory survey and sampling techniques in the form of forcible entry, sampling of 250 respondents in Bank of Metro Madani, Metro City. The results of research: bancassurance products directly affect the conduct of consumer respondent; company image directly affects the conduct of consumers; bancassurance products directly affect to company image.
\end{abstract}

\section{KEY WORDS}

Bancassurance products, responsiveness, corporate image, consumer behavior.

The development of the business in the era of globalization is currently progressing, marked with the level of competition between companies that are increasingly stringent (Chhaochharia et al., 2017; Ling Liao \& Chun Lin). The situation caused the company generally tries to survival, developing company, obtain optimal profit and sought to strengthen the position of the company in the face of competitors. A marketer is required to create the appropriate marketing strategy in order to Jakarta fierce competition with other companies (Kirchner, 2012). The management should be able to create products that are able to provide the characteristics of the consumer themselves in order to know the products marketed by the company (Chhaochharia et al., 2017). To deliver company identity for easy known consumer brands becomes a very important.

In the know consumers, we need to learn about consumer behavior as a manifestation of all the activities of the human soul itself (Anne M., 2017). The customer has the meaning of which is very important for a company, a company is highly unlikely to be able to survive without the support and the existence of consumers. Consumers are the main factor for the existence of a company (Albrecht et al., 2017). Therefore, the orientation on the customers is an absolute requirement that must be held by the company.

Knowing the behavior of consumers will help the company in identifying the market (Fergurson, 2017; Norouzi1, 2013). So the market segment will be more clear, real and effective. Learn about the behavior of consumers can know how consumers make purchases. The behavior of consumers in selecting a product is influenced by several factors among other social factors, a personal and psychological.

Marketing can occur and widespread not only limited in a country, but can only occur across the region between countries. According to (Balqiah, 2015; Khayul, 2012) mentions this consumer behavior exploded along with the emergence of the concept of marketing (marketing concept) in the world of marketing. This concept has the assumption that the company should be able to know and satisfy the desire, improve responsiveness and the needs of the target market (target markets) and able to offer with better than their competitors (Berry et al., 2017; Holweg, 2007). So that this concept has a focus on the 
consumer side is different from other marketing basic philosophy, such as the concept of sales (selling concept) or other concept.

According to (Jackson \& Anderson, 2007; Balqiah 2015) marketing strategy designed to improve the chances of consumers in order to give the response and positive feelings toward products and services for a specific brand and will try the products, services or the brand and buy it repeatedly (it constitutes buying).

Consumers are satisfied with the product or service companies typically will do the purchasing or recurring consumption (it constitutes buying), then they will become the loyal consumers (loyal) and even volunteering for company promotional activities (Puranam, 2017; Bernardes \& Hanna, 2009).

Increasing sales, of course, will have an impact on improving the benefits that implicated to the welfare of the company and stakeholders (owner, top managers, employees, community customers and state). It constitutes buying allows companies to receive a more stable revenue flow or even improve with the word of " (news spread from mouth to mouth) from consumers.

To develop a good marketing strategy, marketer must know the characteristics of its consumers (Wugayan \& Pleshko, 2011; Maja, 2015). To know which customers tend to buy its products, factors what about cause consumers prefer a product compared with other products, what criteria is used for consumer buying decisions, and from which consumers get information about product (Siu et al., 2013). Marketer need to devise a strategy based on the behavior of consumers namely the behavior before the purchase, purchase, and behavior after purchase (Soliman, 2011).

Each product has a life cycle limit banking product is no exception. For that banks are required to produce the products according to the needs of its client (Chhaochharia et al., 2017; Lung Peng, 2015; Paglia \& Phlegar, 2015). In introducing new products to the stakeholders, banking not only using the resources it possesses only (Boubaker, 2017). Banks were also able to take advantage of the resources that are outside of the company name with how to develop cooperation in the form of a strategic alliance. One of the forms of cooperation that is currently gaining popularity in Indonesia is a form of marketing alliance between banking company with the insurance company. Cooperation in the market of banking products and insurance products is then known by the term bancassurance.

Bancassurance as new products produced in cooperation between the bank and insurance, of course, there are still many people that are ambiguous in interpreting. (Sendra, 2007) says that what is meant by the activities of the marketing cooperation between the bank and the insurance company hereinafter referred to as Bancassurance is an act of cooperation between the bank and the insurance company in order to market insurance products through the bank.

Different from other financial services business insurance business management at a glance need extra effort especially for visualization of the uniqueness and utility products offered so that it can be well distributed to the customers (Mukherji \& Ananda M., 2017; Alavudeen, 2015). Bancassurance is one form of the development of the insurance product distribution channels through the present banking institutions. For the bank itself, Bancassurance is a new concept to build better business relationships and protected with the customers (Samaha et al., 2014; Gokalp, 2017).

The awareness of the bank is still a relatively low against the bancassurance is actually a separate question that requires more tracking. But however, bancassurance phenomenon thus indicating great opportunities of collaboration between banking and insurance institutions in meeting the needs of the broader market as well as the practice that occurs in other countries. (Sharma \& Reddy, 2003; Kim et al., 2005; Bergendahl, 1983). Perhaps the one thing that is now required by the perpetrators of the insurance business is to understand the demographic profile and psychographics the inhabitants of this land and made as a basic capital for the development of insurance products.

According to one of the insurance agents in another company (Warsito, 2011; Karimian, 2017; Prakash, 2017), obstacles that cause bancassurance sales target is not achieved is the awareness of the bank is still relatively low against the bancassurance, limits 
the amount of income to get each month, and people think that insurance is not too beneficial.

To know the opinion of bancassurance and corporate value credibility in the eyes of the public or consumer, each company need the response from consumers in order to be used as a research material to take the next steps to be taken by the company. The response from the customers they utilized to measure the level of consumer satisfaction toward the products or services that they offer and also against the company itself (Reichhart et al., 2008).

The level of satisfaction that you want to reach each consumers, of course, is different and varied (Miller et al., 2002). Measuring customer satisfaction is an activity which has an important role in order to succeed in the current business climate. Measuring customer satisfaction can also be made to see how employees respond to the customer. As stated by (Khayul, 2012), that responsiveness as behavior that focuses on consumer, cause consumers will be satisfied if marketer respond to each question consumers quickly. Because each customer will want satisfaction toward goods or services consumed (Liljander, 1990).

Responsiveness include the ability to achieve the goal of taking into account the appropriate time scale with customer requests or changes in markets, to bring or maintain competitive advantages. Emergency power as the ability of the manufacturing system to make adjustments quickly and balanced with the changes predicted and unexpected characterize manufacturing environment today (Albrecht, 2017).

The impression of the experience of the experience that has been received by a person is the image of the company as stated by (Balqiah, 2015), that the image of the company based on what associate with companies or all information (perception, the conclusion, and trust) about what people believe. Trust is very important in building the image of a good company because the trust will generate a good memory and affect the behavior of consumers.

Corporate Image is the impression that appears in the mind of the customer when they hear the name of the product or service company that has been producing products or services. The Image of this company can affect the behavior of the potential customer and can form the purchase decision. The Image of the company is the result of the process in which the subscriber has comparing various companies attribute (El-Salam, 2013). Company image influenced by four things, namely morality, how companies have moral against social environment; management, how well the company manages all resources available; performance, how the performance of the company in its activities; and services (Barbu, 2012; Krakowiak \& Malgorzata, 2013).

The Image of the company must be created, kept and reinforced in the mind of the customer. The Image of a strong company will cause differences from other companies. A strong company image affect consumers in decision-making the purchase. Better company image in the mind of the customer, the higher the customer trust in the company, this will increase the reputation of the company (Meredith et al., 2007; Maden, 2013).

Based on the background and conceptual framework above, this research done to test this hypothesis directly influence positively bancassurance products to consumer behavior, direct effect positive responsiveness to consumer behavior, direct effect positive image of the company to the consumer behavior, direct effect positive bancassurance products to company image and the direct effect positive responsiveness to company image.

\section{METHODS OF RESEARCH}

The approach of research done is the quantitative approach with survey methods. The study was conducted in January and March 2017 in Bank of Metro Madani, Metro City. Research constellation specify bancassurance products is an exogenous variable, responsiveness as exogenous variable, company image exogenous variable for consumer behavior, but as endogenous variables for bancassurance products, responsiveness and company image. 
The target population is all customers of Bank of Metro Madani, Metro City in Lampung Province, the population in the year 2016 as many as 7.654 customers. Samples used 250 customers and the announcement samples by proportional random sampling.

The instrument used in this study is the multiple choice with 5 alternatives and using Likert scale model for bancassurance products variable, responsiveness, company image and consumer behavior. The preparation of the instrument covers the development dimension and the indicator in the preparation of the instrument, testing the validity and reliability of the revision of the instrument, finalization, and data collection.

Testing the validity of the instrument using the biserial correlation (Naga, 1992), and testing the reliability of using the internal consistency reliability coefficient (Steiner, 2003). For the scale of bancassurance products, responsiveness scale, the scale of the image of the company and consumer behavior scale, testing the validity of using chromatic "Product Moment Person" (Bluman, 2008) and testing the reliability of using "Cronbach coefficient's" (Cronbach Alpha, 1963).

Data Analysis Techniques include analysis of descriptive statistics, statistical inference, in linearity test, test and regression significance for the statistics multivariate using path analysis (Structural Equation Modeling). The processing and analysis of the data using Microsoft Excel, SPSS, and LISREL.

\section{RESULTS OF STUDY}

Requirements Analysis Test of Normality. Before doing data analysis, required test data normality analysis requirements as follows:

Table 1 - The Summary of the Test Requirements of the Normality

\begin{tabular}{|c|c|c|c|c|c|}
\hline No. & Error Estimated Regression & $\mathrm{L}_{\text {value }}$ & $\mathrm{L}_{\text {table }}$ & Decision & Conclusion \\
\hline 1 & $\mathrm{Y}_{2}$ on $\mathrm{X}_{1}$ & 0.051 & 0,056 & $\mathrm{H}_{0}$ Acceptable & Normal \\
\hline 2 & $\mathrm{Y}_{2}$ on $\mathrm{X}_{2}$ & 0.043 & 0,056 & $\mathrm{H}_{0}$ Acceptable & Normal \\
\hline 3 & $\mathrm{Y}_{2}$ on $\mathrm{Y}_{1}$ & 0.048 & 0,056 & $\mathrm{H}_{0}$ Acceptable & Normal \\
\hline 4 & $\mathrm{Y}_{1}$ on $\mathrm{X}_{1}$ & 0.054 & 0,056 & $\mathrm{H}_{0}$ Acceptable & Normal \\
\hline 5 & $\mathrm{Y}_{1}$ on $\mathrm{X}_{2}$ & 0.075 & 0,056 & $\mathrm{H}_{0}$ unacceptable & Unnormal \\
\hline
\end{tabular}

Requirements Analysis Test of Homogeneity. The next analysis requirements test stage is homogeneity occurrence, know that samples from homogeneous distribution.

Table 2 - The Summary of the Test Requirements of the Homogeneity

\begin{tabular}{|c|c|c|c|c|}
\hline No. & Variable & $\mathrm{X}_{\text {value }}^{2}$ & $\mathrm{X}_{\text {table }}^{2}$ & Homogenous \\
\hline 1 & $\mathrm{Y}_{1}$ on $\mathrm{X}_{1}$ & 19,334 & 149,885 & Homogenous \\
\hline 2 & $\mathrm{Y}_{1}$ on $\mathrm{X}_{2}$ & 13,362 & 146,567 & Homogenous \\
\hline 3 & $\mathrm{Y}_{2}$ on $\mathrm{X}_{1}$ & 32,399 & 149,885 & Homogenous \\
\hline 4 & $\mathrm{Y}_{2}$ on $\mathrm{X}_{2}$ & 20,998 & 146,567 & Homogenous \\
\hline 5 & $\mathrm{Y}_{2}$ on $\mathrm{Y}_{1}$ & 48,799 & 143,246 & \\
\hline
\end{tabular}

Requirements Analysis Test of Linearity and the significance of Regression. The results of this test is used to determine the relationship between the variables with the requirements that each of the variables must have a linear relationship and regression significances.

Table 3 - The Summary of the test of Requirements and the significance Linearity Regression

\begin{tabular}{|c|c|c|c|c|c|c|}
\hline \multirow{2}{*}{ The variables } & \multicolumn{2}{|c|}{ Sig. Regression } & \multirow{2}{*}{ Sig. Regression } & \multicolumn{2}{|c|}{ Lin. Regression } & \multirow{2}{*}{ Linearity of } \\
\cline { 2 - 3 } & $\mathrm{F}_{\text {value }}$ & $\mathrm{F}_{\text {table }}$ & & $\mathrm{F}_{\text {value }}$ & $\mathrm{F}_{\text {table }}$ & Regression \\
\hline $\mathrm{Y}_{2}$ on $\mathrm{X}_{1}$ & 3.63 & 2.73 & Significant & 0.05 & 2.73 & Linearity \\
\hline $\mathrm{Y}_{2}$ on $\mathrm{X}_{2}$ & 4.37 & 2.73 & Significant & 0,045 & 2.73 & Linearity \\
\hline $\mathrm{Y}_{2}$ on $\mathrm{Y}_{1}$ & 6,02 & 2.73 & Significant & 0.03 & 2.73 & Linearity \\
\hline $\mathrm{Y}_{1}$ on $\mathrm{X}_{1}$ & 328,70 & 2.73 & Significant & 0.09 & 2.73 & Linearity \\
\hline $\mathrm{Y}_{1}$ on $\mathrm{X}_{2}$ & 0.04 & 2.73 & Un Significant & 0,079 & 2.73 & Linearity \\
\hline
\end{tabular}


The results of the calculation of the path Coefficient, $t_{\text {value. After requirement test }}$ analysis is done, next is doing the calculation and testing of each path coefficient as presented in the following image:

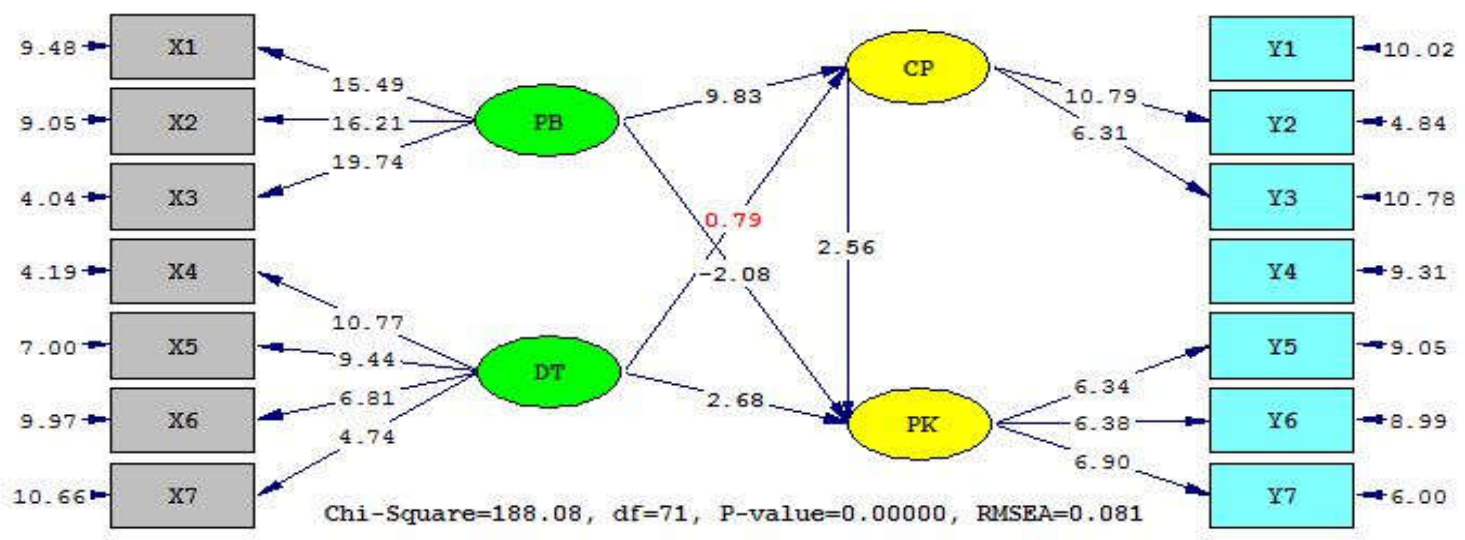

Figure 1 - The Path Model with $t$-value

Table 4 - Result of the Path Coefficient Calculation ( $\left.t_{\text {value }}\right)$

\begin{tabular}{|c|c|c|c|c|c|}
\hline \multirow{2}{*}{ No. } & \multirow{2}{*}{ Variable } & \multicolumn{2}{|c|}{ The Path Coefficients $(\rho)$} & \multirow{2}{*}{ Decision } & \multirow{2}{*}{ Conclusion } \\
\cline { 3 - 4 } & & SLF $^{*}$ & TValue $_{n}$ & & Significant \\
\hline 1 & $\mathrm{Y}_{2}$ on $\mathrm{X}_{1}$ & 0.56 & 2.08 & $\mathrm{H}_{0}$ Unacceptable & Significant \\
\hline 2 & $\mathrm{Y}_{2}$ on $\mathrm{X}_{2}$ & 0.23 & 2.55 & $\mathrm{H}_{0}$ Unacceptable & Significant \\
\hline 3 & $\mathrm{Y}_{2}$ on $\mathrm{Y}_{1}$ & 0.73 & 2.55 & $\mathrm{H}_{0}$ Unacceptable & Significant \\
\hline 4 & $\mathrm{Y}_{1}$ on $\mathrm{X}_{1}$ & 0.89 & 9,83 & $\mathrm{H}_{0}$ Unacceptable & Insignificant \\
\hline 5 & $\mathrm{Y}_{1}$ on $\mathrm{X}_{2}$ & 0,043 & 0,83 & $\mathrm{H}_{0}$ Acceptable & . \\
\hline
\end{tabular}

*Standardized Loading Factor.

The Path coefficient Sub-Structure 1. The path coefficient analysis Model sub-structure 1 is stated in the form of common $Y 1=\beta_{31} X 1+\beta_{32} X_{2}+\varepsilon_{1}$. This testing will give decisionmaking hypothesis test 1 , and 2 .

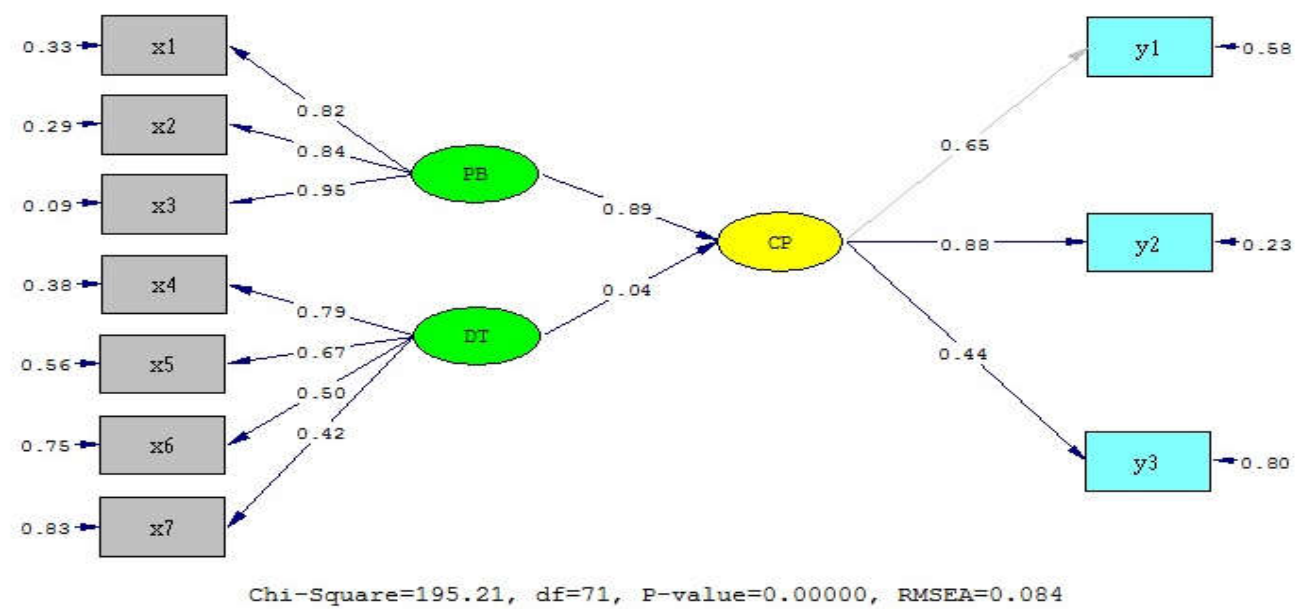

Figure 2 - The Path coefficient Sub-Structure 1

Based on the testing of the sub-structure of 1 obtained coefficient band ( $\beta$ local churchmen) of 0.89 and value of $t_{\text {value }}=9,83>$ table(0.05: 250) $=1.97$ then $\mathrm{H}_{0}$ rejected and path coefficient $\beta_{31}$ local churchmen is significant, means bancassurance products directly affects positively to the image of the company. The path coefficient $\left(\beta_{32}\right)$ of 0.04 and value of $t_{\text {value }}=$ 
$0,83<t_{\text {table }}(0.05: 250)=1.97$ then $H_{0}$ accepted and drag coefficient band ( $\left.\beta 32\right)$ is not significant, means responsiveness not directly affects positively to the image of the company.

The Path coefficient Sub-Structure 2. The path coefficient analysis Model sub-structure 2 is stated in the form of common $Y_{2}=\beta_{41} X_{1}+\beta_{42} X_{2}+\beta_{43} Y_{2}+{ }_{\varepsilon 2}$. This testing will give decision-making hypothesis test 3,4 , and 5 .

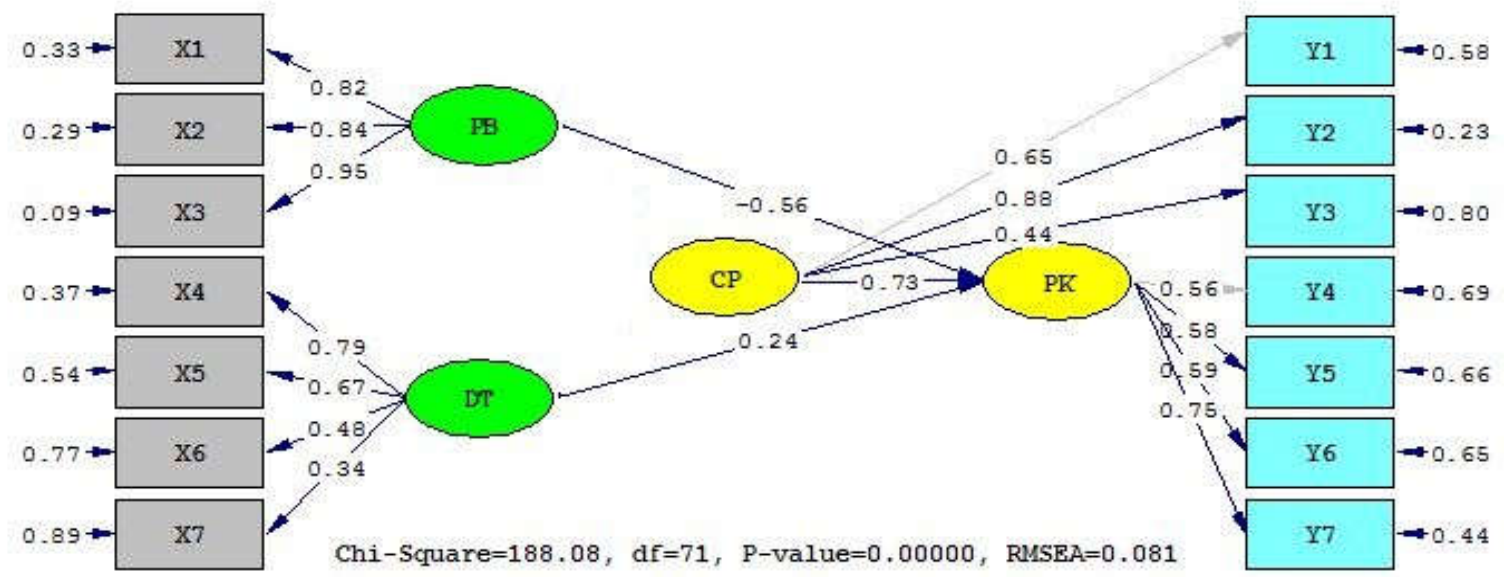

Figure 3 - The Path coefficient Sub-Structure 2

Based on the testing of the sub-structure of 2 obtained coefficient band $\left(\beta_{41}\right)$ of $-0,56$ and value of $t_{\text {value }}=-2,08>t_{\text {table }}(0.05: 250)=1.97$ then $H_{0}$ rejected so path coefficient $\left(\rho_{41}\right)$ is significant. This means that the bancassurance products directly affects the negative against the behavior of consumers. Chromatic band $\left(\beta_{42}\right)$ of 0.24 and value of $t_{\text {value }}=2.55>t_{\text {table }}(0.05$ : $250)=1.97$ then $\mathrm{HO}$ rejected so path coefficient $\left(\beta_{42}\right)$ is significant. This means that the responsiveness directly affects positively to the consumer behavior. Coefficient band ( $\beta 43)$ of 0.73 and value of $t_{\text {value }}=2.55>t_{\text {table }(0.05: 150)}=1.97$ then $H_{0}$ rejected so path coefficient $\left(\beta_{43}\right)$ is significant. This means that the company image directly affects positively to the consumer behavior.

Based on the calculation of the line and the coefficient $t$-value for the purpose of testing the hypothesis that specified, shows that the four path coefficient $>0.05$ and $t$-value $>1.97$, so $\mathrm{H}_{0}$ rejected and four channel is significant.

Overall line diagram standardized solution for each of the variables through the program Lisrel version 8.80 is described as follows:

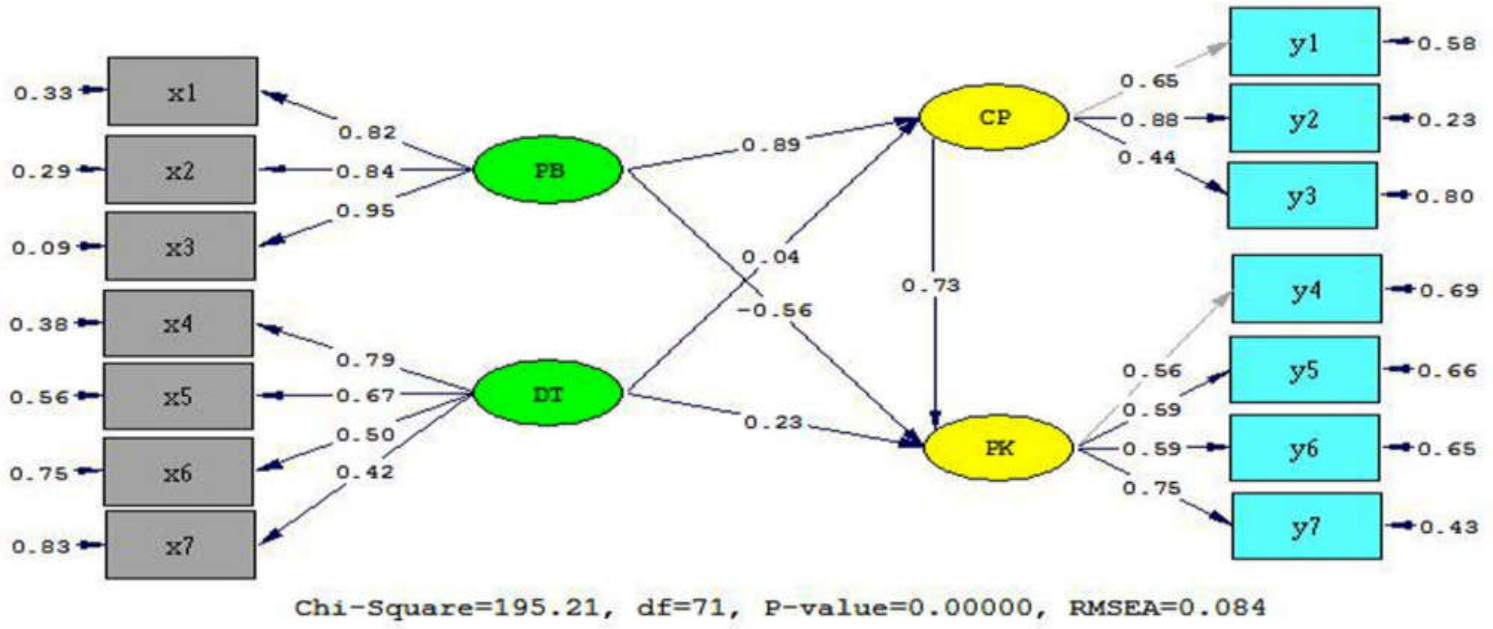

Figure 4 - Line Diagram Standardized Solution 
Based on the picture 4 (Line diagram Standardized Solution), in addition to the existence of the influence of direct), there is also the influence of the total and not directly (indirect) between exogenous variables with the endogenous variable. Based on the lisrel output about standardized total effect shows that: (1) The total value of the influence of (total effect) Bancassurance products variable, responsiveness and the image of the company to the behavior of consumers with the value of the influence of the direct effect of each variables, because it is not mediated by other variables (intervening variable), (2) The total value of the influence of the total effect) bancassurance products variable power and responsive to the image of the company are also the same with the value of the influence of the direct effect of each variables, because it is not mediated by the intervening variable, (3) the influence of indirect effect) bancassurance products variable against the company image of $0.89 \times 0.73=0,650$, due to other variables (intervening variable) The company image of 0.73 , while total influence is $0.23+0,650=0,880$, and (4) the influence of indirect effect variable responsiveness to consumer behavior of $0,043 \times 0.73=0,031$ due to intervening variables namely company image of 0.73 , while total influence is $0.56+0,031=0,591$.

Description of the total influence of exogenous variable against endogenous variable above shows that this variable bancassurance products and responsiveness directly affects positively to the consumer behavior because of the intervening (mediation variable product image has a value greater influence compared with the variables which are not mediated by other variables. In other words, bancassurance products, responsiveness and company image with the same effect the behavior of consumers have value greater influence compared with only one exogenous variable which weighed down the consumer behavior. This also happened in the variable company image, bancassurance products, and responsiveness together affect the image of the company has a value greater influence compared with only one exogenous variable that affects the image of the company.

\section{DISCUSSION OF RESULTS}

There is a positive direct influence on Bancassurance Products Consumer Behavior. Based on the results of the study showed that the influence of bancassurance products consumer behavior. This shows that if in marketing bancassurance products, helping customers choose bancassurance products and offers insurance products done with proper and correct, then the decision-making process, product selection and satisfactory services will increase. So it can be attracted the interest of consumer toward greater bancassurance products.

The results of these findings in accordance with the research done by Nasrul (2014) that consumer behavior have a positive impact on the purchase decision life insurance.

There is a positive direct influence Responsiveness to Consumer Behavior. Based on the results of the study showed that the responsiveness have positive influence directly to the consumer behavior. This shows that if the speed in serving, help difficulties faced by the information and handling complaints very good, then the decision-making process, product selection, satisfactory services and consumer satisfaction will increase.

The results of these findings in accordance with the research done by Tarigan (2014) that the dominant response power variables affect customer loyalty.

There is the direct effect positive image of the Company to the consumer Behavior. Based on the results of the study showed that the image of the company have positive influence directly to the consumer behavior. This shows that if the services services provided satisfactory, its subsidiaries can be trusted, and company identity and clear, then the decision-making process, product selection, satisfactory services and consumer satisfaction will increase.

The results of these findings in accordance with the research done by Putri (2011) that consumer behavior had an effect on the consumer satisfaction choose Oriflame Cosmetics products.

There is a positive direct influence Bancassurance Products to company image. Based on the results of the study showed that bancassurance products have positive influence 
directly against the company image. This shows that if in marketing Bancassurance products, helping customers choose bancassurance products and offers insurance products done with proper and correct, then a satisfactory services, company that can be trusted and company identity will increase.

The results of these findings in accordance with the research done by Prameswari (2011) that the value of the customer is able to increase customer loyalty, advertising appeal is able to increase customer loyalty, and competencies the sellers are able to increase customer loyalty.

There is no direct influence Responsiveness to company image. Based on the results of the study showed that did not affect the responsiveness of consumer behavior. This indicates that the speed in serving, help difficulties faced by the information and deal with complaints is very good and will not affect the quality of service to satisfy, trust to the company and company identity. But the company will continue to serve customers in accordance with the procedures and provide the quality of service to achieve maximum more customer oriented.

The results are not in accordance with the research done by Tarigan (2014) that there is the influence of the responsiveness and empathy for customer loyalty.

\section{CONCLUSION AND SUGGESTIONS}

Based on the results and the discussion of the research, it can be concluded that:

Bancassurance Products affect consumer behavior. This shows that the marketing bancassurance products to our customers and assist customers choose right bancassurance products is the determining factor of the most basic of customer desire. So that it can be said that the bancassurance products have been in accordance with the perception and hope consumer behavior.

Influential responsiveness to consumer behavior. This shows that the customer focus on the speed of the service and help the difficulties experienced by the customers is the factor that can increase the desire to buy consumers so that arise interaction is good. So that it can be said that the responsiveness has been in accordance with the perception and hope consumer behavior.

The Image of the company affect consumer behavior. This shows that a satisfactory services and trust to the company can increase the level of desire and customer satisfaction. So that it can be said that the image of the company is in compliance with the perception and hope consumer behavior.

Bancassurance Products affect the image of the company. This shows that the right bancassurance products offer is one of the determining factor the quality of service.

Responsiveness did not influence the company image. This shows that the responsiveness given by employees on the client, speed in serving the consumers, did not influence directly against the company image, although on the other hand can affect the purchase decision.

Based on the conclusions and implications of the research on the top, then can be recommended a few things as follows:

Bancassurance Products must have innovation and quality is better than that previously so that they can attract customers and potential customers.

The services must be more in increase on when the officers face consumers who have complaints and get difficulties.

The company must provide a satisfactory services so that the image of the company will be better and will always be remembered by the client and potential customers.

\section{REFERENCES}

1. Alavudeen, Rebeena \& Dr. Sr. Rosa K.D. (2015). Growing Role of Bancassurance in Banking Sector. Bonfring International Journal of Industrial Engineering and Management Science, vol. 5, p. 10-16. 
2. Albrecht, Carmen-Maria, Stefan Hattula, and Donald R. Lehmann. (2017). The relationship between consumer shopping stress and purchase abandonment in taskoriented and recreation-oriented consumers. Journal of the Academy of Marketing Science. 45.5 (Sept. 2017) p.720. Word Count: 14591.

3. Anne M. Gessler. (2017). Warriors for lower prices: the New Orleans housewives' league and the consumer cooperative movement, 1913-1921. Journal of Southern History. 83.3 (Aug. 2017) p573. Word Count: 19784.

4. Balqiah, T. E., \& Setyowardhani, H. (2015). Perilaku Konsumen. Tangerang Selatan: Universitas Terbuka.

5. Barbu, Oana. (2012). Brand Cultures: Between Identity and Image. Mediterranean Journal of Social Sciences. Special Issue 3.9 (Apr 2012): 47-53.

6. Bergendahl, Goran. (1983). Subject Area: Marketing. The Profitability of Bancassurance for European Banks. International Journal of Bank Marketing. ISSN: 02652323 Online from: 1983. Vol. 13 issue: 1, pp. 17-28.

7. Bernardes, Ednilson Santos \& Mark D. Hanna. (2009). A Theoretical Review of Flexibility, Agility and Responsiveness in The Operations Management Literature. International Journal of Operations and Production Management, vol. 29, p. 30-53.

8. Berry, Christopher, Scot Burton, and Elizabeth Howlett. (2017). It's only natural: the mediating impact of consumers' attribute inferences on the relationships between product claims, perceived product healthfulness, and purchase intentions. Journal of the Academy of Marketing Science. 45.5 (Sept. 2017) p698. Word Count: 14901.

9. Bluman, Allan G. (2008) Elementary Statistics: A Step by Step Approach. New York: McGraw Hill, 2008.

10. Boubaker, Sabri., Wael Rouatbi, and Walid Saffar. (2017). The Role of Multiple Large Shareholders in the Choice of Debt Source. Financial Management. 46.1 (Spring 2017) p241. Word Count: 12590.

11. Chhaochharia,Vidhi, Yaniv Grinstein, Gustavo Grullon, and Roni Michaely. (2017). Product market competition and internal governance: evidence from the Sarbanes-Oxley Act. Management Science. 63.5 (May 2017) p1405. Word Count: 11775.

12. Cronbach, L. J. (1963). Educational Psychology. New York: Harcourt, Brace \& World, Inc.

13. El-Salam, Eman Mohamed Abd., Ayman Yehia Shawky. And Tawfik El-Nahas. (2013). The impact of corporate image and reputation on service quality, customer satisfaction and customer loyalty: testing the mediating role. Case analysis in an international service company. Arab Academy for Science and Technology and Maritime Transport, College of Management and Technology, Alexandria, Egypt. The Business \& Management Review. Vol.3 Number-2, January 2013.

14. Fergurson, J. Ricky. (2017).Self-image congruence: an empirical look at consumer behavior in door-to-door sales!. Journal of Managerial Issues. 29.3 (Fall 2017) p262. Word Count: 5366.

15. Gokalp, Omer N., Seung-Hyun Lee, and Mike W. Peng. (2017). Competition and corporate tax evasion: An institution-based view. Journal of World Business. 52.2 (Feb. 2017) p258. Word Count: 235.

16. Holweg, M. (2007). The Three Dimensions of Responsiveness. International Journal of Operation and Production Management, vol. 25, p. 603-622.

17. Jackson, Howell E. \& Stacy A. Anderson. (2007). Can states tax national banks to educate consumers about predatory lending practices?. Harvard Journal of Law \& Public Policy. 30.3 (Summer 2007) p831. Word Count: 20801.

18. Karimian, Paniz Haji. (2017). The Effect of Bancassurance on Bank Productivity and Profitability, ARDL Approach (Evidences from Banking Industry in Iran). Economics Department, Tehran University, Tehran, Iran. Scientific \& Academi Publishing. American Journal of Economics. p-ISSN: 2166-4951 e-ISSN: 2166-496X. 2017; 7(4): 177-185. doi:10.5923/j.economics. 20170704.03.

19. Khayul, Susanna, Edmund Prater, Patricia M. Swafford. (2012). International Responsiveness of Entrepreneurial New Ventures From Three Leading Emerging 
Economies. International Journal of Operation and Production Management, vol. 32, p. 1147-1177.

20. Kim, Taehyung, Lucia F. Dunn, and Gene E. Mumy. (2005). Bank Competition and Consumer Search Over Credit Card Interest Rates. Economic Inquiry. 43.2 (Apr. 2005) p344. Word Count: 6336.

21. Kirchner, Theresa A., Ford, John B; Mottner, Sandra. (2012). Disruptive marketing and unintended consequences in the nonprofit arts sector. Arts Marketing; Bingley. Vol. 2, Iss. 1, (2012): 70-90.

22. Krakowiak, Karpinska \& Malgorzata. (2013). The Impact of Consumer Knowledge on Brand Image Transfer in Cultural Event Sponsorship. Polish Sociological Review 182 (2013): 185-208.

23. Liljander, Veronica. (1990). Operations, Logistic \& Quality. International Journal of Service Industry Management. ISSN: 0956-4233 Currently publisher as: Journal of Service Management Online from: 1990 Subject Area: Volume 8, Issue 2. Emotions in service satisfaction

24. Ling Liao, Tsai \& Wen-Chun Lin. (2017). Corporate governance, product market competition, and the wealth effect of R\&D spending changes. Financial Management. 46.3 (Fall 2017) p717. Word Count: 8042.

25. Lung Peng, Jin., Vivian Jeng, Jennifer L .Wang, Yen - Chih Chen. (2015). The Impact of Bancassurance on Efficiency and Profitability of Banks: Evidence from the Banking. Industry in Taiwan. This version: July 10, 2015. Associate Professor, Department of Risk Management and Insurance National Chengchi University, Taiwan.

26. Maden, Deniz. (2013). The Concept of Brand Culture: A Qualitative Analysis Directed to Turkish Airlines. Mediterranean Journal of Social Sciences, suppl. Special Issue 4.10 (Oct 2013): 42-49.

27. Maja et al. (2015). Research of Honey Consumers Behavior in Province of Vojvodina. International Journal of Economics of Agriculture, vol. 3, p. 627-644.

28. Meredith, Lawley; Apisit Chattananon; Jirasek Trimetsoontorn; (2007). Society and Business Review 2.3 (2007): 230-253.

29. Miller, Hertzman, Ruth P; Morgenstern, Hal; Hurwitz, Eric L; Yu, Fei; et al. (2002). Comparing The Satisfaction of Low Back Pain Patients Randomized to Receive Medical or Chiropractic Care: Results from the UCLA low-back pain study. American Journal of Public Health; Washington. Vol. 92, Iss. 10, (Oct 2002): 1628-33.

30. Mukherji, Jyotsna and Ananda M. (2017). Attitudes Toward Pharmaceutical Direct-ToConsumer Advertising: The Role Of Culture. Journal of Competitiveness Studies. 25.2 (Summer 2017) p114. Word Count: 3237.

31. Naga, Dali S. (1992). Pengantar Teori Skor pada Pengukuran Pendidikan. Jakarta: Universitas Negeri Jakarta, 1992.

32. Nasrul, Arista Milka. (2014). Pengaruh Faktor Perilaku Konsumen Terhadap Keputusan Pembelian Asuransi Jiwa. ( Studi pada AJB Bumiputera 1912 Syariah Cabang Cibubur). Fakultas Syariah dan Hukum Universitas Islam Negeri Syarif Hidayatullah Jakarta. 2014.

33. Norouzi1, Abdollah, Ali Akbar Jafarizadeh, Maryam Karbalaei1, Yousef Najafi. (2013). The Effective Major Factor On Customer Perceived Value In Service Context: The Application of ANFIS Method. European Online Journal of Natural and Social Sciences. 2013, Vol. 2, p. 408-416.

34. Paglia, John K. \& Jacquelyn K. Phlegar. (2001). The New Basel Capital Accord: What will be the impact on small banks and consumers? (Community Banking). Bank Accounting \& Finance. 15.2 (Winter 2001) p63. Word Count: 2763.

35. Prakash, Rajshree, Rahul Ravi, and Rubin Zhao. (2017). The anatomy of a socially responsible corporation. Financial Management. 46.1 (Spring 2017) p.33. Word Count: 10575.

36. Prameswari, N. P. (2011). Analisis Faktor-Faktor yang Mempengaruhi Loyalitas Konsumen Pada Asuransi Prudential di Kota Semarang. Semarang: Universitas Diponegoro. 
37. Puranam, Dinesh, Vishal Narayan, and Vrinda Kadiyali. (2017). The Effect of Calorie Posting Regulation on Consumer Opinion: A Flexible Latent Dirichlet Allocation Model with Informative Priors. Marketing Science. 36.5 (September-October 2017) p726. Word Count: 13560.

38. Putri, S. R. (2011). Analisis Perilaku Konsumen Terhadap Kepuasan Memilih Produk Kosmetik Oriflame Pada PT Orindo Alam Ayu Cabang Pekanbaru. Riau: Universitas Islam Negeri Sultan Syarif Kasim.

39. Putri, Sari Rossalina. (2011). Analisis Perilaku Konsumen Terhadap Kepuasan Memilih Produk Kosmetik Oriflame Pada Pt. Orindo Alam Ayu Cabang Pekanbaru. Fakultas Ekonomi Dan IImu Sosial Universitas Islam Negeri Sultan Syarif Kasim. Riau.

40. Reichhart, Andreas, José M. Framiñán \& Matthias Holweg. (2008). Production Coordination and Inventory Policies. Original Articles. On the link between inventory and responsiveness in multi-product supply chains. Journal International Journal of Systems Science. Volume 39, 2008 - Issue 7. Pages 677-688 | Received 10 Dec 2007, Accepted 03 Feb. 2008, Published online: 19 May 2008.

41. Samaha, Stephen A., Joshua T. Beck, \& Robert W. (2014). Palmatier. American Marketing Association. Journal of Marketing. Vol. 78 (September 2014), 78-98. ISSN: 0022-2429 (print), 1547-7185 (electronic).

42. Sendra, K. (2007). Bancassurance : Kemitraan Strategis Perbankan Dengan Perusahaan Asuransi. Jakarta: PPM.

43. Sharma, Pramendra \& Mahendra Reddy. (2003). Empirical modelling of bank market exclusion. (pp. 296 - 303). Published: 2003, Start page: 289. International Journal of Bank Marketing. ISSN: 0265-2323. Volume 21, Issue 6/7 . 2003.

44. Siu, Noel Yee-man; Zhang, Tracy Jun-feng; Yau, Cheuk-ying Jackie. (2013). The Roles of Justice and Customer Satisfaction in Customer Retention: A Lesson from Service Recovery. Journal of Business Ethics: JBE; Dordrecht. Vol. 114, Iss. 4, (Jun 2013): 675686.

45. Soliman, Hisham Sayed. (2011). Customer Relationship Management and Its Relationship to the Marketing Performance. Department of Business Management Faculty of Commerce Cairo University. International Journal of Business and Social Science. Vol. 2 No. 10; June 2011.

46. Steiner, David L. (2003). "Starting at the Beginning: An Introduction to Coefficient Alpha and Internal Consistency." Journal of Personality Assessment, Vol.80, No. 1, 2003, 99103.

47. Tarigan, J. A. (2014). Pengaruh Daya Tanggap Dan Empati Terhadap Loyalitas Pelanggan Pada PT Sriwijaya Air Distrik Medan. Medan: Universitas Sumatera Utara.

48. Warsito. (2011). Tersedia https: //onespirit129.wordpress.com/ 2011/ 04/ 13/ membangun - kesadaran-masyarakat-dalam-berasuransi/2011. (di akses 8 Juni 2017).

49. Wugayan, Adel Al, Larry P. Pleshko. (2011). San Diego State University - Imperial Valley Campus. Study Of Satisfaction, Loyalty, And Market Share In Kuwait Banks Offering Mutual Fund Services. Journal International Business Reseach. Kuwait University. Volume 10, Number 2. 